\title{
Kelayakan dan Strategi Pengembangan Usaha Pembenihan Ikan Patin di CV Mika Distrindo
}

\author{
Feasibility Study and Business Development Strategy of Hatchery Patin Catfish \\ at CV Mika Distrindo
}

\author{
Pindo Witoko*1, Rizal Syarief ${ }^{\# 2}$ dan Sapta Raharja ${ }^{\# 3}$ \\ ${ }^{1}$ Politeknik Negeri Lampung \\ Jl. Soekarno Hatta No. 10 Rajabasa, Bandar Lampung \\ ${ }^{2}$ Departemen Ilmu dan Teknologi Pangan, Fakultas Teknologi Pertanian, Institut Pertanian Bogor \\ ${ }^{3}$ Departemen Teknologi Industri Pertanian, Fakultas Teknologi Pertanian, Institut Pertanian Bogor \\ \#JI. Kamper, Kampus IPB Darmaga, Bogor 16680
}

\begin{abstract}
ABSTRAK
Pengembangan produksi benih ikan Patin memiliki potensi besar untuk memenuhi permintaan pasar. Hambatan dan kendala yang dihadapi oleh pembenih, terutama oleh CV Mika Distrindo adalah pada tahapan produksi sampai pemasaran. Tujuan penelitian: (1) Memperoleh informasi proses produksi pada kegiatan usaha; (2) Mengetahui kelayakan usaha pembenihan ikan Patin di CV Mika Distrindo; dan (3) Mendapatkan strategi pengembangan usaha pembenihan ikan Patin paling efektif dalam memperoleh hasil maksimal. Metode analisis dilakukan dengan (1) Analisis deskriptif untuk mengambarkan proses produksi dalam pembenihan ikan Patin; (2) Analisis kelayakan usaha menggunakan pendekatan net present value (NPV), internal rate of return (IRR), net benefit cost $(\mathrm{B} / \mathrm{C})$ ratio, gross benefit cost $(\mathrm{B} / \mathrm{C})$ ratio, pay back period (PBP), dan break even point (BEP); (3) Analisis lingkungan internal dan eksternal dievaluasi dengan matriks internal factor evaluation (IFE) untuk kekuatan dan kelemahan serta matriks external factor evaluation (EFE) untuk peluang dan ancaman, kemudian di gabungkan dalam matriks internal external (IE); (4) Analisis SWOT (strengths-weaknesses-opportunties-threats) yang memakai variabel internal dan eksternal perusahaan untuk memperoleh alternatif-alternatif prioritas strategi bagi pengembangan usahanya; dan (5) Analisis Quantitative Strategic Planning Matrix (QSPM) untuk pengambilan keputusan alternatif prioritas strategi yang tepat dan terbaik untuk diterapkan bagi pengembangan usaha pembenihan ikan Patin CV Mika Distrindo. Indikasi kelayakan dari segi financial diketahui dari hasil perhitungan dengan kebutuhan biaya investasi Rp509.050.000 dan rataan biaya operasional Rp284.100.000 per tahun menghasilkan nilai NPV Rp516.660.510; IRR 21,42\%; Gross B/C Ratio 5,57; Nett B/C Ratio 4,05; PBP 0,85 tahun atau 10 bulan 5 hari dan BEP pada produksi benih 2.698.006 ekor atau pada nilai penjualan Rp539.601.139,60 (90\%). Dari hasil penjumlahan skor total matriks IFE dan EFE didapatkan nilai masing masing 2,511 dan 2,565 (posisi sedang). Hasil analisis SWOT berupa pemanfaatan kemajuan teknologi, perluasan jaringan pemasaran, penguatan modal, peningkatan volume penjualan, malakukan kemitraan, memanfaatkan investor, meningkatkan loyalitas pelanggan, mempertahankan mutu benih, perbaikan sistem manajemen dan peningkatan kerjasama dengan stakeholder. Implementasi strategi didapat berdasarkan perhitungan matriks QSP adalah meningkatkan volume penjualan benih Ikan Patin.
\end{abstract}

Kata kunci: pembenihan ikan Patin, analisis kelayakan dan strategi pengembangan usaha

\section{ABSTRACT}

The development of larva production of Patin catfish has great potential to meet market demand. CV Mika Distrindo is the one of company that need a development strategy to increase production to meet demand of Patin catfish larva. The aims of this study were: (1) to obtain information on the production process of breeding; (2) to know the feasibility of breeding; and (3) to carry out the strategy of seeding to obtain maximum profit. Method of analysis was done with (1) a descriptive analysis of the production process for a portrait Patin catfish hatchery; (2) Analysis of the feasibility using NPV, IRR, Net B/C Ratio, Gross B/C Ratio, PBP, and BEP; (3) Analysis of internal and external matrix are using IFE and EFE matrix, and in combination in a matrix of IE; 4) SWOT matrix analysis to formulate strategic alternatives; and 5) Analysis QSPM for alternative decision priorities. The study results shows that CV Mika Distrindo is feasible because the business get the financial benefit. Indications in terms of financial feasibility are known from Rp516.660.510 of NPV; $21.42 \%$ of IRR; 5.57 of Gross B/C Ratio; 4.05 of Nett

\footnotetext{
*) Korespondensi:

Jl. Soekarno Hatta No. 10 Rajabasa, Bandar Lampung; e-mail: pindo@polinela.ac.id
} 
B/C Ratio; 10 months and 5 days of PBP and 2.698.006 of larva production or Rp539.601.139,60 of the value of sales. IFE score is 2.511 and EFE score is 2.565 (medium position). The Company core strategy is Growth/Stability Strategy. The SWOT analysis obtains formulation of strategies including the use of advances in technology, expansion of marketing network, strengthening capital, increasing sales volume, doing partnerships, taking advantage of investors, increase customer loyalty, maintain larva quality, improved system management and collaboration with stakeholders.

Key words: Patin catfish hatchery, feasibility analysis and business development strategy

\section{PENDAHULUAN}

Sektor agribisnis memiliki prospek cukup baik untuk dikembangkan adalah bidang perikanan. Salah satu potensi perikanan Indonesia yang berkembang adalah budidaya perikanan (aquaculture). Potensi budidaya perikanan Indonesia diperkirakan seluas 15,59 juta Ha yang terdiri dari budidaya air tawar (2,23 juta $\mathrm{Ha})$, payau (1,22 juta $\mathrm{Ha})$, dan laut (12,14 juta $\mathrm{Ha})$, tetapi pemanfaatannya masih sangat kecil, yaitu untuk tawar baru $10,01 \%(223.223 \mathrm{Ha})$, payau $40 \%(488.000 \mathrm{Ha})$, dan laut 0,01\% (1.214 Ha) (Fadel, 2011).

Salah satu jenis ikan konsumsi air tawar yang memiliki potensi dan banyak digemari oleh masyarakat adalah ikan Patin (Pangasius hypophthalmus), terutama di pulau Sumatera dan Kalimantan, disebabkan rasa daging ikan Patin yang enak, lezat, gurih dan tekstur daging sedikit kenyal. Selain itu, harga ikan Patin relatif terjangkau membuat masyarakat gemar mengkonsumsi ikan jenis ini maka untuk merespon potensi permintaan tersebut, diperlukan suatu kegiatan usaha budidaya ikan Patin.

Keberhasilan usaha pembesaran ikan Patin sangat ditentukan oleh input bermutu dan proses produksi yang baik. Salah satu input produksi tersebut adalah benih. Mutu benih ikan sangat menentukan output pembesaran ikan Patin yang akan dihasilkan. Apabila benih ikan Patin mempunyai mutu yang baik maka kemungkinan besar hasil ikan Patin konsumsi bermutu baik juga (Subamia et al., 2003). Dengan meningkatnya usaha pembesaran ikan Patin, kebutuhan akan benih di tingkat pembesaran semakin meningkat. Peningkatan kebutuhan benih hingga saat ini belum sepenuhnya diimbangi dengan penyediaan benih bermutu baik.

Pengembangan produksi benih ikan Patin memiliki potensi besar untuk memenuhi permintaan pasar. Dalam hal ini, Lampung merupakan salah satu sentra pembesaran ikan Patin, dimana produksi perikanan budidaya terbesar jika dibandingkan dengan komoditas perikanan lainnya (Tribun, 2010). Produksi ikan Patin konsumsi di Propinsi Lampung pada Tahun 2010 menunjukan angka 19.565 ton (Taryono, 2011), maka diduga kebutuhan benih ikan Patin di Lampung 39.130.000 ekor. Jumlah tersebut didapatkan dari asumsi dengan ukuran konsumsi 2 ekor $/ \mathrm{kg}$. Jumlah kebutuhan tersebut masih sangat jauh jika dibandingkan dengan total produksi rataan benih ikan Patin di Lampung, sehingga diperlukan usaha untuk meningkatkan produksi benih ikan Patin di Lampung.

Menurut Hubeis dan Najib (2008), keberadaan suatu perusahaan sangat ditentukan oleh kemampuan untuk memenuhi kebutuhan konsumen secara memuaskan dari segi mutu, ketersediaan, harga dan distribusinya. Sedangkan permintaan konsumen terhadap barang sekarang ini semakin kompleks seiring semakin banyaknya alternatif usaha yang telah ada. Situasi persaingan usaha yang tinggi memaksa CV Mika Distrindo untuk lebih meningkatkan daya saingnya, sehingga mencapai tingkatan superior competitive advantage di antara pesaingnya. Untuk itu perlu adanya strategi pengembangan usaha yang harus dilakukan untuk menghadapi situasi persaingan pada usaha pembenihan ikan Patin.

Penelitian ini bertujuan: (1) Mengkaji infor-masi proses produksi pada kegiatan usaha, (2) Menganalisis kelayakan usaha pembenihan ikan Patin (Pangasius hypopthalmus) di CV Mika Distrindo dan (3) Menyusun strategi pengembangan usaha pembenihan paling efektif untuk memperoleh hasil maksimal.

\section{METODOLOGI}

Penelitian dilaksanakan di CV Mika Distrindo yang beralamatkan di Desa Sumbersari, Kecamatan Metro Selatan, Kota Metro, Lampung. Pelaksanaan kajian kurang lebih selama empat (4) bulan, yaitu pada bulan November 2011Februari 2012. Kajian ini menggunakan metode deskriptif dan analitik yang bersifat studi kasus dimana data yang telah terkumpul akan dideskripsikan atau digambarkan sebagaimana adanya. Untuk mengidentifikasi dan mengevaluasi lingkungan perusahaan (internal dan eksternal) dilakukan wawancara langsung dengan responden menggunakan kuesioner, observasi langsung dan studi kepustakaan. Sementara data eksternal merupakan data dari pembanding dari luar suatu organisasi yang dapat menggambarkan faktorfaktor yang mungkin memengaruhi hasil kerja suatu organisasi. Hasil identifikasi kemudian dianalisis, sehingga diketahui posisi perusahaan saat ini, selanjutnya dilakukan analisis kelayakan usaha dan prospek pengembangan usaha ke depan yang dapat diimplementasikan.

Analisis kelayakan dilakukan untuk melihat apakah usaha yang dijalankan tersebut layak atau tidak dengan melihat kriteria investasi yaitu Net Present Value (NPV), Internal Rate of Return 
(IRR), Net Benefit/Cost (B/C) ratio, Gross B/C ratio, Payback Period (PBP), dan perhitungan Break Even Point (BEP). Untuk menganalisis kelayakan usaha diperlukan data keuangan perusahaan. Data yang diperoleh dipergunakan sebagai dasar perhitungan untuk analisis proyeksi keuangan. Analisis proyeksi keuangan dilakukan dengan metode cash flow. Hasil proyeksi keuangan menjadi dasar bagi perhitungan NPV, IRR, Net $\mathrm{B} / \mathrm{C}$ ratio, Gross $\mathrm{B} / \mathrm{C}$ ratio, $\mathrm{PBP}$, dan $\mathrm{BEP}$.

Analisis Pengembangan Usaha mencakup data internal dan eksternal perusahaan yang menjadi faktor kunci dan berpengaruh terhadap perkembangan perusahaan. Data tersebut merupakan data ordinal yang dianalisis dengan matriks Internal Factor Evaluation (IFE), External Factor Evaluation (EFE), Internal-External (IE), Strengths, Weaknesses, Opportunities and Threats (SWOT) dan Quantitatif Strategic Planning Matrix (QSPM). Matriks IFE dan EFE bertujuan menganalisis faktor lingkungan, baik internal maupun eksternal CV Mixa Distrindo. Matriks IE digunakan untuk pemetaan terhadap skor total matriks IFE dan EFE yang dihasilkan dari audit eksternal dan internal perusahaan. Matriks IE terdiri atas dua (2) dimensi, yaitu total skor dari matriks IFE dan total skor dari matriks EFE.

Analisis SWOT adalah identifikasi berbagai faktor secara sistematis untuk merumuskan strategi perusahaan. Analisis ini berdasarkan pada logika yang memaksimalkan kekuatan (strengths) dan peluang (opportunities), namun secara bersama dapat meminimalkan kelemahan (weaknesses) dan ancaman (threats). Proses pengambilan keputusan strategik selalu berkaitan dengan pengembangan misi, tujuan, strategi dan kebijakan perusahaan. Dengan demikian perencanaan strategi (strategic planner) harus menganalisis faktor-faktor strategis perusahaan (kekuatan, kelemahan, peluang dan ancaman) dalam kondisi yang ada saat ini. Hal ini disebut dengan analisis Situasi. Model yang paling popular untuk analisis situasi adalah analisis SWOT (Rangkuti, 2008).

Matriks perencanaan strategi kuantitatif atau QSPM adalah alat yang memungkinkan penyusunan strategi untuk mengevaluasi alternatif strategi secara obyektif, berdasarkan faktor keberhasilan kunci internal dan eksternal yang telah diidentifikasi dan membutuhkan penilaian intuitif yang baik. Secara konsep, QSPM menentukan daya tarik relatif dari berbagai strategi berdasarkan seberapa jauh faktor keberhasilan kunci internal dan eksternal dimanfaatkan atau diperbaiki. Daya tarik relatif dari masing masing strategi dalam satu set alternatif dihitung dengan menentukan pengaruh komulatif dari masing masing faktor keberhasilan kunci internal dan eksternal.

\section{HASIL DAN PEMBAHASAN}

CV Mika Distrindo berlokasi di Desa Sumbersari, Kecamatan Metro Selatan, Kota Metro, Lampung. Lokasi perusahaan berada di pinggiran kota atau lingkungan pedesaan yang masih terjaga sumber daya alam (SDA) pendukungnya. Posisi ini tergolong strategik karena tidak terlalu jauh dari jalan raya, sehingga memudahkan untuk kegiatan distribusi, pemasaran dan pemasokan bahan baku.

Visi perusahaan yang berbasis perikanan, menjadikan kegiatan pembenihan ikan Patin sebagai fokus usaha dalam kegiatannya. Sejak berdiri dengan nama awal Mika Fish Farm, telah memiliki misi untuk "menjadi perusahaan penghasil benih ikan Patin yang mengutamakan mutu, kuantitas dan kontinuitas dalam memproduksi benih, serta senantiasa melakukan perbaikan-perbaikan secara terus menerus dan meningkatkan mutu pelayanan terhadap konsumen". Selain itu perusahaan berkeinginan untuk memberikan lapangan pekerjaan dan peningkatan pendapatan masyarakat sekitar.

Pembenihan adalah kegiatan pemeliharaan induk untuk menghasilkan telur sampai dengan larva (Yulfiperius et al., 2003). Pendederan adalah kegiatan pemeliharaan benih ikan Patin hasil pembenihan untuk mencapai ukuran tertentu dan sebagai masa adaptasi sebelum dipelihara di tempat pembesaran. Agar dapat memperoleh produk benih sesuai dengan target kuantitas dan mutu yang diharapkan serta tepat waktu sesuai dengan permintaan, maka dalam proses produksi benih ikan Patin terdapat beberapa persyaratan yang harus dipenuhi (Effendi et al., 2006).

\section{Analisis Kelayakan Usaha}

Komponen biaya dalam analisis kelayakan usaha pembenihan ikan Patin dibedakan menjadi dua, yaitu biaya investasi dan biaya operasional. Biaya investasi adalah komponen biaya yang diperlukan untuk memenuhi kebutuhan dana awal pendirian usaha yang meliputi lahan/areal usaha, pembuatan kolam induk dan kolam pendederan, panti benih, peralatan dan sarana produksi. Sedangkan biaya operasional adalah seluruh biaya yang harus dikeluarkan dalam proses produksi.

Aliran kas (cash flow) dalam perhitungan ini dibagi dalam dua aliran, yaitu arus masuk (cash inflow) dan arus keluar (cash outflow). Arus masuk diperoleh dari penjualan benih ikan Patin selama satu tahun. Untuk arus keluar meliputi biaya investasi, biaya variabel, biaya tetap dan penyusutan.

Evaluasi profitabilitas rencana investasi dilakukan dengan menilai kriteria investasi untuk mengukur kelayakan pendirian usaha pembenihan Patin, yaitu meliputi NPV, IRR, Net B/C Ratio, Gross B/C Ratio, PBP, dan BEP. Hasil perhitung- 
an kelayakan usaha pembenaihan ikan Patin CV. Mika Distrindo dilihat pada Tabel 1.

Usaha pembenihan ikan Patin di CV Mika Distrindo dengan pemilihan pola usaha dan menggunakan asumsi yang ada menghasilkan NPV Rp516.660.510, menunjukkan bahwa nilai yang dihasilkan lebih besar dari 0 (nol), maka dikatakan usaha tersebut feasible untuk dilaksanakan. Jika nilai NPV $=0$, maka usaha tersebut dalam keadaan BEP. Pada tingkat suku bunga $14 \%$ didapatkan nilai IRR 21,42\%, menunjukkan nilai persentase IRR lebih dari 0 (nol). Gross B/C Ratio 5,57 dan Net B/C Ratio 4,05 memiliki nilai $>1$ berarti cash in flows lebih besar daripada cash out flows atau total revenue lebih besar dari pada total cost atau dengan kata lain setiap satu rupiah pengeluaran atas biaya tunai akan memberikan penerimaan Rp5,57 dan Rp4,05 Berdasarkan kriteria dan asumsi yang ada menunjukkan bahwa usaha pembenihan ikan Patin dengan skala minimal yang dipilih ini sudah layak untuk dilaksanakan dengan PBP selama 0,85 tahun atau 10 bulan 5 hari, berarti bahwa dalam kurun waktu tersebut total cost yang dikeluarkan sama dengan total revenue yang diterima. Titik impas (BEP) usaha pembenihan ikan Patin berada pada produksi benih 2.698.006 ekor atau pada nilai penjualan Rp539.601.139,60, itu berarti pada nilai tersebut suatu usaha sudah dapat dikatakan kembali modal.

Tabel 1. Kelayakan usaha pembenihan ikan Patin CV Mika Distrindo

\begin{tabular}{cccc}
\hline No & Kriteria & Nilai Justifikasi & Kelayakan \\
\hline 1. & NPV (Rp) & 516.660 .510 & $>0$ \\
2. & IRR (\%) & 21,42 & $>14$ \\
3. & Gross B/C Ratio & 5,57 & $>1,00$ \\
4. & Net B/C Ratio & 4,05 & $>1,00$ \\
5. & PBP & 0,85 tahun & 10 bulan 5 \\
& & hari \\
6. & BEP & 2.698 .006 & \\
& (ekor) & $539.601 .139,60$ \\
\hline
\end{tabular}

\section{Identifikasi Faktor Kekuatan, Kelemahan, Peluang dan Ancaman}

Berdasarkan hasil analisis lingkungan internal perusahaan berupa kekuatan dan kelemahan serta kondisi eksternal perusahaan yang meliputi peluang dan ancaman yang berpengaruh terhadap pengembangan usaha pembenihan ikan Patin dan selanjutnya diidentifikasi faktor-faktor kekuatan, kelemahan, peluang, serta ancamannya. Hasil analisis tersebut akan digunakan untuk menetapkan posisi perusahaan dengan menggunakan matriks IE, yang akan dipetakan posisi suatu perusahaan dalam suatu diagram. Setelah mengetahui posisi perusahaan, selanjutnya hasil tersebut digunakan untuk merumuskan alternatif starategi bisnis ke dalam analisis SWOT. Berikut ini dikemukakan kekuatan, kelemahan, peluang dan ancaman CV
Mika Distrindo yang terdapat pada profil SWOT pada Tabel 2 .

\section{Analisis Matriks IFE dan EFE}

Berdasarkan identifikasi terhadap faktorfaktor internal perusahaan berupa kekuatan (strengths) dan kelemahan (weaknesses) yang berpengaruh terhadap pengembangan bisnis pemasaran ikan Patin. Melalui kuisioner yang telah diisi oleh pemilik perusahaan dan manajer produksi perusahaan CV Mika Distrindo yang dianggap pakar dan memiliki kapasitas sebagai pengambil keputusan dalam perusahaan, kemudian dilakukan pembobotan dengan menggunakan metode paried comparison sehingga diperoleh bobot dari masing-masing variabel internal perusahaan. Demikian pula dengan pemberian peringkat (rating), penentuan peringkat dilakukan oleh dua responden yang sama dan data yang diambil adalah data rata-rata dari kedua responden tersebut, sehingga didapatkan nilai terboboti dari faktor-faktor tersebut.

\section{Matriks IFE}

Berdasarkan hasil perhitungan pada Tabel 3 , produk mempunyai spesifikasi standar nasional sebagai faktor paling penting dalam kegiatan produksi (skor 0,413) dan merupakan kekuatan yang dimiliki perusahaan untuk memberikan yang terbaik bagi konsumen. Hal ini terkait dengan adanya komitmen pihak manajemen terhadap mutu benih yang dihasilkan (skor 0,391).

Kurangnya promosi yang dilakukan perusahaan menjadi kelemahan yang dapat menghambat dari perkembangan perusahaan (skor 0,218). Hal tersebut berkaitan dengan sistem manajemen organisasi yang belum mendukung (skor 0,207), dimana pengaturan kerja dalam perusahaan belum tertata sesuai dengan prosedur suatu manajemen.

\section{Matriks EFE}

Berdasarkan hasil perhitungan pada Tabel 4 terlihat bahwa adanya hubungan antara permintaan pasar yang cukup besar (skor 0,433 ) akan meningkatkan pula daya beli benih bermutu (skor 0,378). Guna mendapatkan benih yang bermutu dengan adanya kemajuan teknlogi dalam pembenihan (skor 0,360), maka keinginan tersebut dapat tercapai. Ancaman terkuat adalah dengan adanya perusahaan pendatang baru sejenis dapat memengaruhi perkembangan usaha, apalagi perusahaan baru tersebut bermodal kuat.

\section{Matriks IE}

Hasil evaluasi dan analisis yang telah dilakukan, selanjutnya dilakukan analisis IE untuk menghasilkan matriks IE, sehingga dapat diketahui posisi perusahaan untuk mempermudah pemilihan alternatif strategi. 
Pemetaan posisi perusahaan sangat penting bagi pemilihan alternatif strategi dalam menghadapi persaingan dan perubahan yang terjadi dalam usaha pembenihan ikan Patin. Dengan total nilai pada matriks internal 2,511, maka CV Mika Distrindo memiliki faktor internal yang tergolong sedang atau rata-rata dalam melakukan usaha pembenihan ikan Patin. Total nilai matriks eksternal 2,565 memperlihatkan respon yang diberikan oleh CV Mika Distrindo kepada lingkungan eksternal tergolong sedang. Secara lengkap matriks IE dan posisi perusahaan CV Mika Distrindo dapat dilihat dalam Gambar 1.

Tabel 2. Profil SWOT CV Mika Distrindo

\begin{tabular}{|c|c|}
\hline Kekuatan (S) & Kelemahan (W) \\
\hline 1. Benih yang dihasilkan bermutu baik & 1. Kekurangan permodalan untuk pengembangan usaha \\
\hline 2. Teknologi proses produksi cukup baik & 2. Pemasaran belum optimal \\
\hline 3. Produk mempunyai spesifikasi standar nasional & 3. Kurangnya promosi hasil produksi \\
\hline 4. Usaha dijalankan langsung dan dipantau oleh pemilik & 4. Kapasitas produksi belum optimal \\
\hline 5. Tenaga kerja cukup terampil & 5. Sistem manajemen organisasi belum mendukung \\
\hline Peluang (0) & Ancaman (T) \\
\hline 1. Permintaan pasar cukup besar & 1. Keberadaan perusahaan lain yang sejenis \\
\hline 2. Kemajuan teknologi dalam pembenihan & 2. Kurangnya daya dukung pemerintah \\
\hline 3. Mendorong berkembangnya 119 ector perikanan & 3. Ada perusahaan pendatang baru sejenis \\
\hline 4. Meningkatnya daya beli benih bermutu & 4. Kondisi cuaca kurang stabil \\
\hline 5. Peningkatan pendapatan masyarakat sekitar & 5. Sulitnya sumber pembiayaan \\
\hline
\end{tabular}

Tabel 3. Perhitungan Matriks IFE CV Mika Distrindo

\begin{tabular}{lccc}
\hline \multicolumn{1}{c}{ Faktor Strategik Internal } & Bobot & Rating & Skor \\
\cline { 2 - 4 } & (a) & (b) & (axb) \\
\hline A. Kekuatan & & & \\
1. Benih yang dihasilkan bermutu baik & 0,098 & 4,000 & $\mathbf{0 , 3 9 1}$ \\
2. Teknologi proses produksi cukup baik & 0,101 & 3,000 & $\mathbf{0 , 3 0 2}$ \\
3. Produk mempunyai spesifikasi standar nasional & 0,103 & 4,000 & $\mathbf{0 , 4 1 3}$ \\
4. Usaha dijalankan langsung dan dipantau oleh pemilik & 0,106 & 3,000 & $\mathbf{0 , 3 1 8}$ \\
5. Tenaga kerja cukup terampil & 0,095 & 3,000 & $\mathbf{0 , 2 8 5}$ \\
Jumlah (A) & & & $\mathbf{1 , 7 0 9}$ \\
\hline B. Kelemahan & & & \\
1. Kekurangan permodalan untuk pengembangan usaha & 0,101 & 1,000 & $\mathbf{0 , 1 0 1}$ \\
2. Pemasaran belum optimal & 0,092 & 1,500 & $\mathbf{0 , 1 3 8}$ \\
3. Kurangnya promosi hasil produksi & 0,109 & 2,000 & $\mathbf{0 , 2 1 8}$ \\
4. Kapasitas produksi belum optimal & 0,092 & 1,500 & $\mathbf{0 , 1 3 8}$ \\
5. System manajemen organisasi belum mendukung & 0,103 & 2,000 & $\mathbf{0 , 2 0 7}$ \\
Jumlah (B) & & & $\mathbf{0 , 8 0 2}$ \\
\hline \multicolumn{1}{c}{ Total (A+B) } & & $\mathbf{2 , 5 1 1}$ \\
\hline
\end{tabular}

Tabel 4. Perhitungan Matriks EFE CV Mika Distrindo

\begin{tabular}{lccc}
\hline \multicolumn{1}{c}{ Faktor Strategik Eksternal } & Bobot & Rating & Skor \\
\cline { 2 - 4 } & $\mathbf{( a )}$ & $\mathbf{( b )}$ & $\mathbf{( a x b )}$ \\
\hline A. Peluang & & & \\
1. Permintaan pasar cukup besar & 0,108 & 4,000 & $\mathbf{0 , 4 3 3}$ \\
2. Kemajuan teknologi dalam pembenihan & 0,103 & 3,500 & $\mathbf{0 , 3 6 0}$ \\
3. Mendorong berkembangnya sektor perikanan & 0,094 & 3,000 & $\mathbf{0 , 2 8 3}$ \\
4. Meningkatnya daya beli benih bermutu & 0,094 & 4,000 & $\mathbf{0 , 3 7 8}$ \\
5. Peningkatan pendapatan masyarakat sekitar & 0,100 & 3,000 & $\mathbf{0 , 3 0 0}$ \\
Jumlah (A) & & & $\mathbf{1 , 7 5 4}$ \\
\hline B. Ancaman & & & \\
1. Keberadaan perusahaan lain yang sejenis & 0,097 & 1,500 & $\mathbf{0 , 1 4 6}$ \\
2. Kurangnya daya dukung pemerintah & 0,111 & 1,500 & $\mathbf{0 , 1 6 7}$ \\
3. Ada perusahaan pendatang baru yang sejenis & 0,122 & 2,000 & $\mathbf{0 , 2 4 4}$ \\
4. Kondisi cuaca kurang stabil & 0,092 & 1,500 & $\mathbf{0 , 1 3 8}$ \\
5. Sulitnya sumber pembiayaan & 0,078 & 1,500 & $\mathbf{0 , 1 1 7}$ \\
Jumlah (B) & & & $\mathbf{0 , 8 1 1}$ \\
\hline \multicolumn{1}{c}{ Total (A+B) } & & & $\mathbf{2 , 5 6 5}$ \\
\hline
\end{tabular}


Total Skor Faktor strategi Internal = 2,511
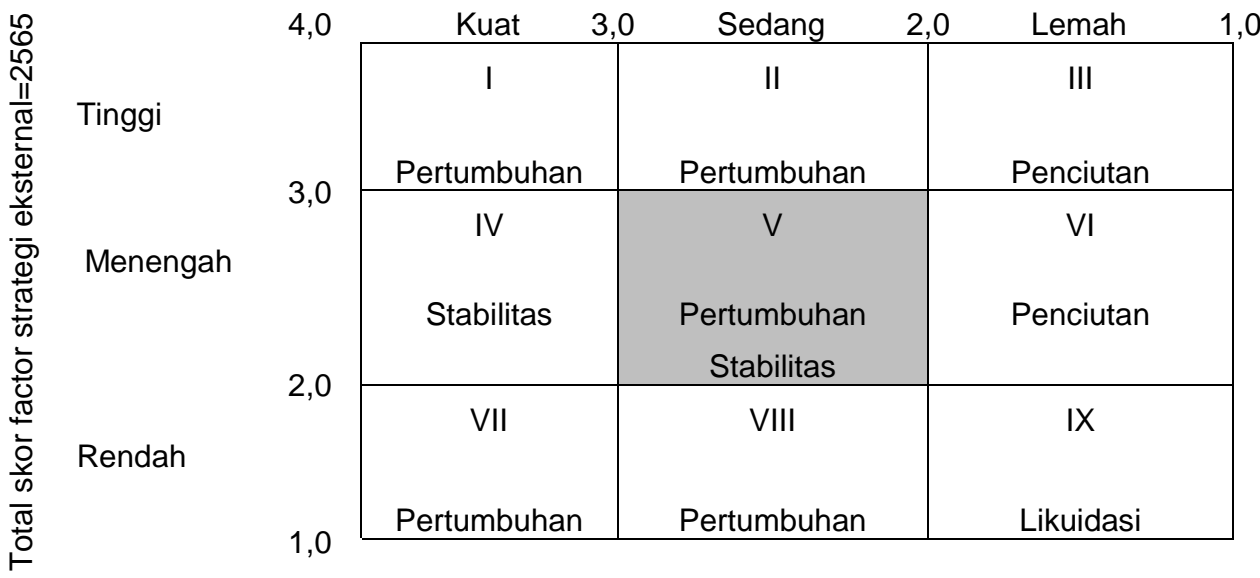

Gambar 1. Matriks IE CV Mika Distrindo

Apabila masing-masing total skor dari faktor internal maupun eksternal dipetakan dalam matriks, maka posisi perusahaan saat ini adalah pada kotak di kuadran kelima, yang berarti inti strategi yang diterapkan perusahaan adalah Strategi Pertumbuhan/Stabilitas. Strategi yang disarankan adalah strategi penetrasi pasar (market penetration), pengembangan produk (market development) dan pengembangan pasar (product development). Strategi penetrasi pasar yang dilakukan oleh perusahaan adalah dengan memberikan harga spesial bagi pelanggan yang mengambil benih ikan Patin secara kontinu dan dalam jumlah yang besar. Strategi pengembangan produk yang dilakukan adalah lebih meningkatkan lagi mutu benih ikan Patin yang dihasilkan. Strategi pengembangan pasar adalah menambah konsumen baru. Jika dilihat dari nilai kriteria kelayakan yang jauh berada di atas standar kelayakan, menunjukkan bahwa dalam partumbuhan perusahaan masih dapat ditingkatkan lagi untuk mencapai mencapai titik puncah/optimum.

\section{Analisis Matriks SWOT}

Perumusan strategi melalui identifikasi dan analisis faktor-faktor internal yang terdiri dari kelemahan dan kekuatan, serta faktor-faktor eksternal yang terdiri dari peluang dan ancaman. Kekuatan merupakan kompensasi khusus yang memberikan keunggulan komparatif bagi usaha pembenihan ikan Patin CV Mika Distrindo, sedangkan kelemahan merupakan keterbatasan atau kekurangan dalam sumber daya keterampilan, maupun kemampuan yang dapat menghambat kinerja perusahaan. Peluang merupakan merupakan situasi yang diinginkan atau disukai dalam lingkungan industri, sedangkan ancaman merupakan situasi yang tidak diinginkan atau tidak disukai dalam lingkungan industri (Rangkuti, 2008).
Setelah mengetahui posisi perusahaan saat ini dan diperoleh inti strategi perusahaan, maka selanjutnya menyusun faktor-faktor strategi bagi perusahaan dengan menggunakan matriks SWOT. Hasil perumusan dikelompokkan menjadi empat kelompok perumusan startegi yang terdiri dari strategi Kekuatan-Peluang (S-O), strategi Kekuatan-Ancaman (S-T), strategi KelemahanPeluang (W-O), dan strategi Kelemahan-Ancaman (W-T), seperti yang disajikan pada Tabel 5.

\section{Analisis Matriks QSP}

Penentuan strategi dilakukan berdasarkan hasil alternatif strategi yang diperoleh melalui analisis matriks I-E dan matriks SWOT. Alat analisis yang digunakan pada tahap ini adalah QSPM. Matriks QSP adalah alat yang memungkinkan ahli strategi untuk mengevaluasi strategi alternatif secara obyektif, berdasarkan pada faktor-faktor sukses kritis internal dan eksternal yang diketahui sebelumnya. Analisis QSPM memerlukan penilaian intuitif yang baik. Alternatif-alternatif strategi yang dimaksud adalah:

1. Memanfaatkan kemajuan teknologi untuk menghasilkan benih lebih bermutu.

2. Memperluas jaringan pemasaran dengan melakukan penetrasi terhadap pasar.

3. Memperkuat permodalan untuk perluasan usaha.

4. Meningkatkan volume penjualan benih ikan Patin.

5. Melakukan kemitraan dengan petani di sekitar yang lebih kecil.

6. Memanfaatkan investor untuk peningkatan modal.

7. Meningkatkan loyalitas pelangan terhadap mutu benih Patin yang dihasilkan.

8. Menjaga dan mempertahankan mutu benih ikan Patin agar diterima oleh konsumen.

9. Perbaikan sistem manajemen usaha di berbagai bidang.

10. Meningkatkan kerjasama dengan stakeholder 
Berdasarkan hasil perhitungan dalam matriks QSP, diperoleh strategi paling tepat untuk diimplementasikan adalah meningkatkan volume penjualan benih ikan Patin dengan total nilai daya tarik tertinggi di antara alternaf-alternatif strategi lainnya (skor 5,398). Urutan prioritas strategi dari matriks QSP dapat dilihat pada Tabel 5.

Dari hasil semua alternatif strategi yang disusun, baik faktor internal dan eksternal memiliki skor total $\geq 4,000$. Hal ini berarti semua strategi yang dikembangkan sangat menarik dan layak untuk dikembangkan, dengan memperhatikan kesiapan waktu dan tempat, kebijakan yang mendukung di tingkat pemerintah daerah dan pusat, iklim usaha untuk permodalan dan keorganisasian baik di dalam maupun di luar perusahaan berupa asosiasi.

\section{Implementasi Strategi}

Pengelompokan alternatif strategi yang dapat dilakukan terhadap strategi-strategi pilihan yang yang didapatkan dibagi dalam tiga (3) kelompok strategi, yaitu dari proses produksi, pemasaran dan permodalan yang dapat dijadikan acuan guna pengembangan usaha pembenihan ikan Patin.

Tabel 5. Rumusan strategi pengembangan dengan matriks SWOT CV Mika Distrindo

\begin{tabular}{|c|c|c|}
\hline Faktor Internal & $\begin{array}{l}\text { Faktor Kekuatan (S) } \\
\text { 1. Benih yang dihasilkan bermutu } \\
\text { baik } \\
\text { 2. Teknologi proses produksi cukup } \\
\text { baik } \\
\text { 3. Produk mempunyai spesifikasi } \\
\text { standar nasional } \\
\text { 4. Usaha dijalankan langsung dan } \\
\text { dipantau oleh pemilik } \\
\text { 5. Tenaga kerja cukup terampil }\end{array}$ & $\begin{array}{l}\text { Faktor Kelemahan (W) } \\
\text { 1. Kekurangan permodalan untuk } \\
\text { pengembangan usaha } \\
\text { 2. Pemasaran belum optimal } \\
\text { 3. Kurangnya promosi hasil produks } \\
\text { 4. Kapasitas produksi belum optimal } \\
\text { 5. Sistem manajemen organisasi } \\
\text { belum mendukung }\end{array}$ \\
\hline $\begin{array}{l}\text { Faktor Peluang (O) } \\
\text { 1. Permintaan pasar cukup besar } \\
\text { 2. Kemajuan teknologi dalam } \\
\text { pembenihan } \\
\text { 3. Mendorong berkembangnya } \\
\text { sektor perikanan } \\
\text { 4. Meningkatnya daya beli benih } \\
\text { bermutu } \\
\text { 5. Peningkatan pendapatan } \\
\text { masyarakat sekitar }\end{array}$ & $\begin{array}{l}\text { Strategi SO (agresif) } \\
\text { 1. Memanfaatkan kemajuan } \\
\text { tekhnologi untuk menghasilkan } \\
\text { benih lebih bermutu } \\
\text { (S1 S2 S3,O2,O4) } \\
\text { 2. Memperluas jaringan pemasaran } \\
\text { dengan melakukan penetrasi } \\
\text { terhadap pasar } \\
\text { (S1,S3,S4,O1,O4) } \\
\text { 3. Memperkuat permodalan untuk } \\
\text { perluasan usaha }(\mathrm{S} 4, \mathrm{O} 3, \mathrm{O} 5)\end{array}$ & $\begin{array}{l}\text { Strategi WO (diversifikasi) } \\
\text { 1. Meningkatkan volume penjualan } \\
\text { benih ikan Patin } \\
\text { (W2,W3,W4,O1,O4) } \\
\text { 2. Melakukan kemitraan dengan } \\
\text { petani di sekitar yang lebih kecil } \\
\text { (W1,W4,O1,O4) } \\
\text { 3. Memanfaatkan investor untuk } \\
\text { peningkatan modal } \\
\text { (W1,W4,O2,O3) }\end{array}$ \\
\hline $\begin{array}{l}\quad \text { Faktor Ancaman (T) } \\
\text { 1. Keberadaan perusahaan lain yang } \\
\text { sejenis } \\
\text { 2. Kurangnya daya dukung } \\
\text { pemerintah } \\
\text { 3. Ada perusahaan pendatang baru } \\
\text { yang sejenis } \\
\text { 4. Kondisi cuaca kurang stabil } \\
\text { 5. Sulitnya sumber pembiayaan }\end{array}$ & $\begin{array}{l}\text { Strategi ST (diferensiasi) } \\
\text { 1. Meningkatkan loyalitas pelanggan } \\
\text { terhadap mutu benih ikan Patin } \\
\text { yang dihasilkan } \\
\text { (S1,S2,S3,S4,T1,T3) } \\
\text { 2. Menjaga dan mempertahankan } \\
\text { mutu benih ikan Patin agar } \\
\text { diterima oleh konsumen } \\
\text { (S1,S2,S3,S5,T2,T4) }\end{array}$ & $\begin{array}{l}\text { Strategi WT (defensif) } \\
\text { 1. Perbaikan sistem manajemen } \\
\text { usaha di berbagai bidang } \\
\text { (W1,W2,W3,W4,W5,T1,T3) } \\
\text { 2. Meningkatkan kerjasama dengan } \\
\text { stakeholder } \\
\text { (W1,W2,W3,W4,T2,T5) }\end{array}$ \\
\hline
\end{tabular}

Tabel 5. Urutan prioritas strategi dari matriks QSP CV Mika Distrindo

\begin{tabular}{llcc}
\hline & \multicolumn{1}{c}{ Alternatif Strategi } & $\begin{array}{c}\text { Total Nilai } \\
\text { Daya Tarik }\end{array}$ & $\begin{array}{c}\text { Urutan } \\
\text { Prioritas }\end{array}$ \\
\hline 1. & Memanfaatkan kemajuan tekhnologi untuk menghasilkan benih yang lebih & 5,314 & 2 \\
& bermutu & & \\
2. & Memperluas jaringan pemasaran dengan melakukan penetrasi terhadap pasar & 5,298 & 3 \\
3. & Memperkuat permodalan untuk perluasan usaha & 5,122 & 7 \\
4. & Meningkatkan volume penjualan benih ikan Patin & 5,398 & 1 \\
5. & Melakukan kemitraan dengan petani di sekitar yang lebih kecil & 5,094 & 9 \\
6. & Memanfaatkan investor untuk peningkatan modal & 4,889 & 10 \\
7. & Meningkatkan loyalitas pelangan terhadap mutu benih ikan Patin yang & 5,223 & 5 \\
& dihasilkan & 5,215 & 6 \\
8. & Menjaga dan mempertahankan mutu benih ikan Patin agar diterima oleh & & \\
& konsumen & 5,239 & 4 \\
9. & Perbaikan sistem manajemen usaha di berbagai bidang & 5,114 & 8 \\
10. Meningkatkan kerjasama dengan stakeholder &
\end{tabular}


Alternatif strategi jangka pendek yang dapat dilakukan adalah memperluas jaringan pemasaran, meningkatkan volume penjualan, pemanfaatan kemajuan teknologi, melakukan kemitraan, perbaikan sistem manajemen, meningkatkan loyalitas pelangan, serta menjaga dan mempertahankan mutu benih.

Alternatif strategi jangka panjang yang ditargetkan adalah strategi dalam rangka memperkuat permodalan untuk perluasan usaha, memanfaatkan investor untuk peningkatan modal dan meningkatkan kerjasama dengan stakeholder (Nazaruddin et al., 2011). Alternatif tersebut memerlukan waktu yang relatif lebih lama karena dalam pelaksanaannya memerlukan proses dan perlu melihat hasil yang telah dijalankan untuk dapat meyakinkan investor memberikan bantuan modal.

Pada saat ini CV Mika Distrindo lebih memprioritaskan upaya memperluas atau mengembangkan pasar, mengingat para konsumen potensial belum banyak yang terjangkau sepenuhnya (Pearce dan Robinson, 1997). Sebagian besar konsumen merupakan pelangan tetap dan loyal, maka strategi pengembangan pasar ditunjukkan untuk meningkatkan volume penjualan dengan tetap menjaga mutu benih ikan Patin yang dihasilkan.

\section{KESIMPULAN}

Urutan kegiatan yang dilakukan pada proses produksi usaha pembenihan ikan Patin di CV. Mika Distrindo, diantaranya pengelolaan induk, seleksi induk, pemijahan, penetasan telur, pemeliharaan larva, pendederan benih, pemanenan dan penanganan hasil panen.

Analisis kelayakan usaha pembenihan ikan Patin di CV Mika Distrindo dikatakan layak, karena dari hasil perhitungan yang dilakukan memberikan manfaat (benefit) secara financial. Indikasi kelayakan dari segi financial diketahui dari hasil perhitungan dengan kebutuhan biaya investasi Rp509.050.000 dan rataan biaya operasional Rp284.100.000 per tahun menghasilkan nilai NPV Rp516.660.510, IRR 21,42\%, Gross B/C Ratio 5,57, Nett B/C Ratio 4,05, PBP selama 0,85 tahun atau 10 bulan 5 hari dan BEP pada produksi benih 2.698.006 ekor, atau pada nilai penjualan Rp539.601.139,60.

Strategi pengembangan usaha pembenihan yang paling efektif adalah meningkatkan volume penjualan benih ikan Patin, memanfaatkan kemajuan teknologi untuk menghasilkan benih lebih bermutu, memperluas jaringan pemasaran dengan melakukan penetrasi terhadap pasar, perbaikan sistem manajemen usaha di berbagai bidang dan meningkatkan loyalitas pelangan terhadap mutu benih ikan Patin yang dihasilkan.

\section{DAFTAR PUSTAKA}

Effendi I., D. Augustine dan Widanarni. 2006. Perkembangan Enzim Pencernaan Larva Ikan Pain (Pangasius hypophthalmus). Jurnal Akuakultur Indonesia, 5(1): 41-49.

Fadel, M. 2011. Sambutan Menteri Kelautan dan Perikanan Republik Indonesia pada Acara Temu Koordinasi Pemantapan Pelaksanaan Kegiatan Pembangunan Perikanan Budidaya.

http://www.kkp.go.id/index.php/archives/c/2/ 3831/sambutan-menteri-kelautan-danperikananrepublik-indonesia-pada-acaratemu-koordinasi-pemantapan-pelaksanaankegiatan-pembangunanperikananbudidaya/. [21 Desember 2011].

http://lampung.tribunnews.com/m/read/artik el/18685/. Produksi-Ikan-Patin-Lamteng150-Ton [21 Desember 2011].

Hubeis, M. dan M. Najib. 2008. Manajemen Strategik dalam Pengembangan Daya Saing Organisasi. Elex Media Komputindo, Jakarta.

Nazaruddin, R., Suryahadi dan M. Sarma. 2011. Analisis strategi Pemasaran Peternakan Ayam Cv. Intan Jaya Abadi Sukabumi, Jurnal Manajemen IKM, 6(2): 152-132.

Pearce, J.A. and Robinson. 1997. Manajemen Strategik: Formulasi, Implementasi dan Pengendalian, (Terjemahan Jilid I). Bina Rupa Aksara, Jakarta.

Rangkuti, F. 2008. Analisis SWOT Teknik Membedah Kasus Bisnis. Gramedia Pustaka Utama, Jakarta.

Subamia, I.W., N. Suhenda dan E. Tahapari. 2003. "Pengaruh Pemberian Pakan Buatan dengan Kadar Lemak yang Berbeda terhadap Pertumbuhan dan sintasan Benih Ikan Jambal Siam (Pangasius hypopthalmus). Jurnal Penel. Perikanan Indonesia, 9 (1): 37-42.

Taryono. 2011. Menggenjot Produksi Perikanan Budidaya.

http://lampung.tribunnews.com/2011/11/20/ menggenjot-produksi-perikanan-budidaya [21 Desember 2011].

Tribun. 2010. Produksi ikan Patin di Lampung Tengah Selama Tahun 2010 ini Mencapai 150 Ton.

Yulfiperius, I. Mokoginta dan D. Jusadi. 2003. Pengaruh Kadar Vitamin E dalam Pakan Terhadap Kualitas Telur Ikan Patin (Pangasius hypophthalmus). Jurnal Iktiologi Indonesia, 3 (1): 11-18. 